\title{
perifèria
}

Número 10, Junio 2009

www. periferia.name

\section{Territori i etnodesenvolupament entre els maies contemporanis de Quintana Roo, Mèxic}

\author{
Jaume Amargant i Paniello \\ Departament d'Antropologia social y cultural-UAB
}

\section{Resum}

L'Estat de Quintana Roo, Mèxic, ha sofert pregones tranformacions causades per formes mercantils d’entendre el territori i l'entorn. Davant de l'acció hegemònica dels governs i les grans empreses, els maies tenen una visió diferenciada del territori, més plural, que combina els sabers autòctons modelats històricament per l'aportació colonial europea amb la ciencia i tecnologia occidentals. Aquestes pràctiques prenen forma a través de l’etnodesenvolupament, una nova manera d'incorporar els sabers locals al corpus de coneixement general sobre els ecosistemes. ¿Com conceben els maies actuals el concepte de territori? ¿Com opera el seu sistema de referències per designar les entitats que habiten l'entorn? ¿Com es relacionen els sabers maies amb les accions de mobilitat sòcioespacials que porten a terme? Aquí intento respondre aquestes preguntes deconstruïnt la dualitat naturalesa/cultura pròpia del pensament occidental per incorporar un punt de vista holístic propi dels sistemes de referència maies.

Paraules clau: maies, sabers locals, sabers autòctons.

\begin{abstract}
Quintana Roo Mexican state suffered dramatic changes in their environment because the strong mercantilization of its territory. Facing this hegemonic action from Mexican State and International Firms, the Maya people envisone their territory from a plurality of views, merging local knowledge and colonial historical processes together with Western Technology and Science. These practices are visible thanks to the "etnodevelopment", a way to incorporate local knoweldge in the general knowledge about ecosystem. How Maya people understand their territory? What is the reference system for the elements present in their environment? What is the relationship between the local knowledge and their patterns of mobility? In this article I try to answer these questions through the deconstruction of the Western duality Nature/Culture and the incorporation of Maya knowledge.
\end{abstract}

Key words: Maya, local knowledge, TEK. 


\section{perifèria}

Número 10, Junio 2009

www.periferia. name

\section{I ntroducció}

Durant la dècada dels anys noranta vaig tenir la sort i el privilegi de viure a la península de Yucatán, Mèxic, on vaig realitzar els estudis en Ciències Antropològiques. Una gran part d’aquestes vivències van transcórrer a l`Estat de Quintana Roo on vaig ésser testimoni de processos accelerats de transformació del territori i de I'entorn. Aquesta experiència em va permetre visualitzar les pregones modificacions en les formes de pensar i de sentir el medi ambient dels pobles maies que I'habiten, causades per l’hegemonía de formes d’apropiació i ús mercantil d'aquest territori. Els goberns estatal i federal i les grans empreses quantifiquen i cosifiquen els espais sobre la base de l'anàlisi despeses-beneficis, basats en el principi de la societat tecnotrònica on domina el paradigma que tot el que resulta tècnicament possible de fer s'ha de fer (Fromm, 1980)

Davant d’aquests discursos utilitaristes del territori i l'entorn, els grups maies locals s' han organitzat per a presentar les seves maneres de comprendre aquest territori com un lloc on habiten entitats no humanes que requereixen $d$ ' un medi per viure i conviure. Espais que són objecte de moviments migratoris, de peregrinacions rituals i de reivindicació sobre els drets culturals. M`interessava comprendre el complexe gent-biodiversitat ( $\mathrm{Paz}, 1998$ ) des de la perspectiva dels sabers maies i la forma com aquest grup humà utilitza el territori i els ecosistemes. En definitiva volia saber com posen en pràctica llurs formes de movilitat sòcioespacials.

El treball de Màster en antropologia social que vaig realitzar a la Universitat Autònoma de Barcelona fou el marc dins del que vaig formalitzar I'estudi d’aquesta situació. Per portar-lo a terme vaig fer una recollida exhaustiva d`informació documental i bibliogràfica sobre les formes d’entendre i practicar el territori dels maies contemporanis de Quintana Roo. Aquí presento un resum d’aquest treball posant èmfasi principalment en la cosmovisió i en els usos dels ecosistemes locals. Per fer-ho parteixo de la idea que cal donar a conèixer les alternatives maies a la pràctica i ús dels territoris com una energia que enriqueixi el 


\section{perifèria}

Número 10, Junio 2009

www. periferia. name

diàleg de sabers (Boada y Toledo, 2003)

Seguint les aportacions teòriques de Philippe Descola (2005) aquí deconstrueixo la dicotomía naturalesa/cultura, dualisme que ha estat històricament construït primer per a comprendre la realitat occidental i després per a definir el caràcter de les societat no occidentals. Diu Maceiras (2007) que matèria i esperit, vida i pensament, determinisme i llibertat, naturalesa i cultura, no són epifenòmens els uns dels altres, sino funcions emergents en llur totalitat, com un sistema obert, itinerant cap a la novetat creativa, amb llurs correspondències i enllaços. Més enllà d’una visió dual i etnocèntrica, per a molts pobles del món el cosmos és una configuració holística que no admet la separació de categories excloents. Al contrari, el treball que comentaré més endavant de Valentina Vapnarsky (2000) demostra que els maies de Quintana Roo utilitzen formes de saber dialògiques $\mathrm{i}$ relacionals a través de formes culturals expressives i dramatitzades com les peregrinacions dels Santos Patronos.

Segons Leff (2002) la crisi ambiental ha provocat l'emergència de sistemes de referència de sabers indígenes les característiques dels quals són l’aparició de noves subjectivitats junt amb el desig de perdurar a través de les diferents combinacions de sabers. Aquí veurem com els maies, com altres pobles del món, han posat en pràctica una síntesi de coneixements que englova una nova versió de la cosmovisió cristiana amb imatges de les religions pre-conquesta i d’altres que han anat incorporant situacionalment segons el moment històric. Per tant, tota intervenció sobre els territoris, tota expolotació dels ecosistemes de Quintana Roo, hauria de tenir en compte les visions imminents en els llenguatges i les formes d’acció maies.

L' emergència d’organitzacions indígenes planteja als sabers hegemònics, és a dir, els d'Occident, el dilema de repensar els termes amb els que aquests han transformat i representat l’entorn. Si bé la preocupació ecològica va començar a Occident, la creació de noves identitats en el món amerindi ha insertat aquest tema al corpus de reivindicacions territorials. Els líders indígenes d'avui mobilitzen 


\section{perifèria}

Número 10, Junio 2009

\section{www. periferia.name}

recursos simbòlics propis (mítico-històrics i cosmològics) com a via per arribar a un estatut etnopolític (Albert, 2004). Molts d’aquests repertoris reivindicatius han estat elaborats a partir de llur lògica cultural específica. A més d’aquests sabers propis els pobles aborígens han incorporat I'univers ideològic de les ONG's al seu corpus epistemològic.

El concepte de territori indígena sobre el que treballo aquí és el que contempla la inclusió d’una doble vertent com a espai de representació i com a espai d'ús comunal o intercomunal (Balza, 2001), territori que no es construeix sobre la base d’una substància concreta o simbòlica sino com la suma de sensibilitats paisatgístiques, valors patrimonials i afectius diversos i formes de movilitat (Di Méo et Buléon, 2005), territori que també importa als estats que elaboren polítiques per dominar-lo, utilitzar-lo o intercambiar-lo. Estats, grups ètnics, agrupacions que realitzen formulacions argumentades sobre discursos que formen part del que en podríem dir representacions territorials (Lasserre et Lechaume, 2003). En aquest article sistematitzo el conjunt de sabers locals que conformen la memòria col-lectiva dels maies contemporanis de Quintana Roo en relació al territori i llurs vincles amb I’entorn. També abordo el concepte d’etnodesenvolupament i llurs posibles usos entre aquesta població en el marc del seu propi codi de representacions amb els que elaboren el que Garret Cook (2000) anomena com una cultura expressiva.

Aquí designo als agents principals com a maies perquè és el nom amb el que se'ls ha donat a conèixer en els estudis etnològics regionals i pels que se'ls adjudica una identitat substantiva i temporalment genèrica (Gutiérrez Estévez, 2006). Parteixo de la idea que existeixen múltiples formes d’entendre el terrritori que es resumeixen bàsicament en dues: com a espai político-administratiu i com a espai cultural o etnoterritorio (Barabas et al., 2003) L’espai i la població objecte d’aquest estudi abarca la franja del territori de Quintana Roo que va desde l’ecosistema coster fins a la selva perennifòlia interior. L’èmfasi principal, 


\section{perifèria}

Número 10, Junio 2009

\section{www.periferia.name}

tanmateix, és a la Zona Maya ${ }^{1}$ constituïda per una franja de l' interior de I’ Estat on la major part de població adopta la identitat maia entre d`altres possibles.

\section{Transformacions de I`entorn}

Segons els censos del Instituto Nacional de Estadística, Geografía e Informática a 1995 un 63\% del territori de Quintana Roo estava cobert per selva baixa i mitjana, un ecosistema molt ric i complex que conté una gran diversitat de flora i fauna (Ruz et. al., 1999). En el context del tròpic humit mexicà és on els avantpassats dels maies contemporanis van desenvolupar llur gran civilització en una de les més brillants adaptacions al bosc plujós subtropical (Demarest, 2006) El segon gran ecosistema és el marí que ocupa tota la línia costera de l'Estat i conté la segona barrera de corall més llarga del món. Els aiguamolls i manglares formen part també del paisatge de Quintana Roo i constitueixen el tercer ecosistema.

La regió de Quintana Roo conté aquests tres ecosistemes sobre els que s`hi ha donat processos d'apropiació humana i l'establiment d’espais antròpics que han provocat un seriós deteriorament. Aquí utilitzo el terme apropiació en el sentit que Boada y Toledo (2003) qualifiquen com l’acte pel que els éssers humans fem nostre un objecte de I'entorn prèviament objectivat i cosificat per convertir-lo en un element social. Els maies de Quintana Roo, en canvi, han portat amb èxit experiències locals d`estructuració comunitària que combinen els sabers propis amb I`aprofitament adeqüat de la biodiversitat local.

Quintana Roo ha sofert des dels anys 70's unes pregones transformacions en el seu entorn cristal.litzades en un conjunt de mesures la finalitat de les quals és modernitzar el territori. Entre els elements de major impacte que he pogut apreciar

\footnotetext{
${ }^{1}$ Nom amb el que els orgnismes oficials designen el territori que ocupen la major part de població maia de Quintana Roo a l'actualitat i que es relaciona amb pràctiques i ritualitats pròpies, una organització social de carácter autònom amb una jerarquia político-religiosa anomenada cruzoob. La Zona Maya és un espai caracteritzat per ser on habiten unes 60,000 persones d'aquest grup ètnic els marcadors culturals dels quals son la pràctica de la llengua maia, peregrinacions a santuaris dels Santos Patronos, veneren el.lements de la religió mesoamericana com l'arbre sagrat o Ceiba i en general on recreen $\mathrm{i}$ reprodueixen tècniques antigues i contemporànies a través d`un patró estètic propi.
} 


\section{perifèria}

Número 10, Junio 2009

\section{www. periferia.name}

els darrers anys puc esmentar la construcció d una ciutat dins la selva (Cancún); construcció acelerada d’infraestructures viàries i complexes hotelers (Riviera Maya), augment demogràfic accelerat de les petites poblacions, en fi, tot molt coherent amb el model d’expansió propi de l’economia neoliberal amb el seu discurs jerarquitzat i la lògica del mercat.

En aquests complexe procés d`apropiació de l'entorn, I’impacte dels canvis sobre els ecosistemes locals ha estat colpidor. Aquests canvis han afectat especialment a la progresiva destrucció del bosc humit tropical, destrucció de l’arrecife i l'extinció de les dunes costeres i del aiguamolls, entre altres. Un dels problemes més importants ara mateix és l’absència total de drenatge a les grans poblacions com Playa del Carmen o Zama (Tulum) el que provoca la contaminació de les aigües subterrànies que a la península de Yucatán són nombroses degut al seu orígen càrstic.

Aquest conjunt de mesures modernitzadores, pel que fa a I`Estat de Quintana Roo, està constituit principalement per la construcció de I’autopista Cancún-Tulum, extensió de les granges de bestiar i la ramaderia extensiva i la col.lonització dels diferents ecosistemes. Aquests processos d'ocupació del territori és coherent amb I'idea de l'utilitarisme present en les concecions mercantils de l'entorn que van marcant una frontera regional del desenvolupament (Albert, 2004). Aquí veiem com el conepte esmentat és hereu del principi medieval europeu de terra nullis que literalment significa "terra buida" és a dir la noció segons la qual els territoris no europeus no tenen propietaris i están buits; per tant poden ésser explotats pels europeus (Posey, 2002). Aquest dicurs del desenvolupament és el mateix que propugna la idea d’un progrés constant i el creixement sostenible, metáfora que I'economia de mercat fa servir per enmascarar el predomini del sistema de sabers occidental sobre els coneixements locals.

Les principals conseqüències de I avenç d'aquesta frontera regional es manifesten en I'estudi realitzat per Ruz et., al. (1999) a Quintana Roo on detectava la degradació de l’entorn a través de l’estensió dels pastizales on abans hi havia 


\section{perifèria}

Número 10, Junio 2009

\section{www. periferia.name}

selva, obertura de grans forats al bosc tropical per a l`extracció forestal, extensió del monocultiu i la desarticulació del sòl amb la conseqüent pèrdua de coneixement local (Sillitoe, 2002). L’ocupació antròpica del territori s` ha produït a través de la política de col.lonització del territori, no articulada per la competencia entre dependències gubernamentals, la substitució dels aiguamolls per complexos turístics i la substitució de fauna local per aliena, entre d`altres.

Per portar a terme la transformació del territori les institucions oficials i les empreses han posat en moviment la maquinària d’extracció de recursos naturals i humans disponibles a la regió. D`una banda la política de col.lonització del tròpic del gobern mexicà contempla les grans àrees forestals com un espai buit, un contenidor de recursos disponible per a ésser explotat i habitat sense límits. D`altra banda les grans empreses hoteleres disposen en aquests moments a Quintana Roo de mà d'obra poc remunerada d`orígen maia provinent de les comunitats locals i de 「`Estat veí de Yucatán.

No obstant la formidable força de transformació amb la que el poder gubernamental i empresarial posa en marxa la maquinària de dominació i tranformació del territori i llurs entitats, aquí veiem com els maies realitzen una selecció adaptada dels diferents fluxes de coneixement (Hannerz, 1992). Amb això plantegen un altre tipus de modernitat alternativa a la hegemònica. En ocasions pot ésser que rebutgin el saber hegemònic occidental però també en altres poden complementarlo amb la propia cosmovisió, la qual ens parla d un sistema de referència ambiental i territorial basat en formes de complementarietat no excloents. Com analitzarem en el següent apartat dins la cosmovisió maia hi ha una visió intersubjectiva del territori segons la qual altres formes d’alteritat (humanes i no humanes) estan presents com a entitats subjectives (Gutiérrez Estévez, 1992; Lenkersdorff, 1996; Pitarch, 1996)

\section{Cosmovisions maia i entorn}

Les creences i rituals dels maies contemporanis de Quintana Roo descansen sobre un model cosmològic conformat per la síntesi de la cosmovisió dels avantpassats i 


\section{perifèria}

Número 10, Junio 2009

\section{www. periferia.name}

el cristianisme. En el contacte entre nadius americans i europeus els maies de la península de Yucatán iniciaren una nova versió de la teologia cristiana amb la seva corresponent expressió en el ritual, la estètica i en I’espiritualitat (Gutiérrez Estévez, 1995) Ells han construït una nova versió interpretativa del cristianisme del que han elaborat imatges que han anat incorporant situacionalment i que els han servit com a inventari personal sobre el que destriar a cada moment històric.

La recerca d’una expressió purament indígena avui en dia resulta romàntica i antihistòrica ja que priva a aquests actors socials no només de les dimensions de llur cultura destruides per la conquista sinó també dels beneficis que han tingut amb l'ús i incorporació de la tectnologia europea a llurs pràctiques socials. La població actual maia de Quintana Roo té una cosmovisió cristiana que aglutina també elements de les religions mesoamericanes amb l'apropiació de nous coneixements adquirits a les escoles i als mitjans de comunicacio massius, com exemplifiquen les dades següents.

D' acord amb Barabas (2003), en el seu sistema de sabers, els maies actuals incorporen elements de la tradició mesoamericana que contempla la idea de I’ existencia de tres grans espais: el ka'an (cel), el yóokolkab (superficie terrestre) i el yáanal lu'um (inframón). L’oficiant religiós o jmeen quan resa invoca a les deitats i als iik' (vents) als seus llocs o cantonades: kan ti'its ka'an (les quatre cantonades del cel) i kan ti'its lu'um (quatre cantonades de la terra) D`altra banda, en contrast amb les filosofies monológiques, la filosofia maia és una filosofia del diàleg, o sigui, que la culpa de les accions recau, no en I individu sino en la comunitat en general (Burns, 1993) Ells posen en pràctica una relació empàtica entre el sol, el bosc, el poble i la regió, relació que abarca també el subsòl, la terra i el cel junt amb les entitats que I’ habiten.

Com veiem els maies no cosifiquen ni objectivitzen la realitat sino que aquesta está nutrida d’ésser sobrenaturals; com els yumtsilo'ob (senyors dignes o mercaders), entitats no humanes vinculades a la tradició oral maia; els balamob (encarregats de la protecció de les persones, la milpa i el poble); els kuilob-kaaxob (els que vigilen 


\section{perifèria}

Número 10, Junio 2009

\section{www.periferia.name}

els boscos); els chacob (els que porten els núvols i la pluja); totes aquestes són subjectes que habien el bosc amb aparença humana. D'acord amb Amador (1993) aquestes tres categories no són més que reminiscències $d$ 'un sol ésser que es manifesta en funció de les ocasions donades en que l’identifiquen. Quan els maies de Quintana Roo porten a terme activitats d'aprovisionament com la caça o el cultiu de la milpa s'accionen un conjunt $d `$ actes rituals que propicien l`enteniment entre éssers humans i no humans, com els acabats d’esmentar.

En la tradició mesoamericana l`entorn s`ha d`entendre com un espai on $s^{\prime}$ interrelacionen elements de sacralitat $a m b$ el territori. Alguns d`aquests espais son concebuts com animats, posseïts per entitats poderoses que a voltes tenen una relació amb els humans de carácter filial. Tant a l'interior de Yucatán com a Quintana Roo els balam kaho'ob son els jaguars guardians del poble, felins que segons Aviña (2000) s`identifiquen amb el poder i amb els yumtzilo'ob o cuidadors del bosc. A la comunitat de Noh Bec (Quintana Roo) algunes persones identifiquen als arbres de manera antropomorfa associant la resina a la sang, les branques a uns braços, entre d’altres elements. (Ruz, et. al. 1999).

Les entitats geològiques i minerals també formen part activa com a subjectes en la construcció de l'entorn dels maies. Els cuyos o centres cerimonials dels maies prehispànics, runes del que foren edificis d`una savia civilització d’arquitectes i astrònoms, son objecte de veneració dels maies contemporanis durant el divendres de Setmana Santa. Aquestes pedres estan protegides igualment per entitats del passat que viuen en forma no humana però que poden intervenir en el present (Gutiérrez Estévez, 1995). Aquí veiem com s`entrellacen els fets històrics amb el mite i com la visió mesoamericana s’articula amb el cristianisme per esdevenir una narració perfectament articulada i cristal.litzada en una nova cosmovisió. Així doncs el bosc existeix com una realitat física. Però és igualment un discurs de pràctiques i representacions, formulades per diversos actors socials de manera que la natura real no es revela i és només perceptible a través del filtre cultural (Lasserre et Lechaume, 2003) 


\title{
perifèria
}

\author{
Número 10, Junio 2009
}

www. periferia. name

Alhora, ells maies contemporanis de Quintana Roo són majoritàriament catòlics, evangèlics, adventistes o testimonies de Jehová i per tant això vol dir que tenen incorporat el cristianisme dins el seu corpus de coneixements. Ells van adoptar la cosmovisió cristiana a la època colonial, formes de pensament de les que ha quedat una pregona petjada en forma de peregrinacions dels Santos Patronos, el culte a la Virgen de Guadalupe i l’asistencia a actes rituals pertanyents a aquesta tradició. Aquestes peregrinacions jo les considero també pràctiques sòcioespaials i son, per tant, en termes de Di Méo i Buléon (2005) unes matrius històriques i espacials.

La cosmovisió dels maies contemporanis contempla la idea que existeix un espai compartit, territori practicat i que tant pot servir per portar a terme rutes de sacralitat com extreure' $n$ herbes curatives. D'altra banda separar ambdúes categories seria un exercici d’essencialització que està en la direcció oposada als pressupostos antidualistes des dels que parteixo. És significatiu, precisament, que en Ilengua maia no existeixin paraules que es puguin traduïr com "naturalesa" o "cultura". Aquest procés d’incorporació no dóna orígen a un sincretisme - en el sentit d`amalgama de_corrents i procedències diverses configurant un nou sistemasino a un ús regulat d ambdues tradicions. Aquesta és la lògica que fan servir els maies contemporanis de Quintana Roo, una lògica on la presència contigua en la mateixa configuració cultural d`elements que semblen contradictoris son tractats de manera pragmàtica com altament preferencials o merament acumulatius (Gutiérrez Estévez, 2006)

\section{Territoris}

Quins son els usos i significats del territori entre els maies contemporanis de Quintana Roo? Per començar ja no trobem una paraula per traduïr "territori" en llengua maia. No obstant i això sabem que territori i cultura son dues fonts que alimenten la identitat. Cada poble i cada ètnica ha anat conformant, dintre de llur procés de desenvolupament històric, diferències que el fan únic (Lomelí, 1999) La noció de territori entre els maies correspon a quelcom no pensat sino més aviat viscut, transitat, un espai subjecte d’ésser explotat però també contstruït per migracions i peregrinacions. Un territori que les organitzacions pan-maies estan 


\section{perifèria}

Número 10, Junio 2009

\section{www.periferia.name}

incorporant als sabers locals en forma de significats polítics, com demandes d'autonomia, un ús particular de la terra o com a lloc per ésser expropiat i ocupat per viure.

Els models rellevants de la construcció del territori indígena són les pautes lògiques que regeixen llur expressió espacial. Aquest etnoterritorio és el lloc on es desenvolupa llur organització social, vida econòmica i ofereix un marc on portar a terme llurs pràctiques socials dins del corpus dels sabers maies. Un espai on es reuneixen els marcadors territorials, culturals i etnopolítics producte de les diferents reelaboracions realitzades al Ilarg de la història. El concepte de territori que he considerat pertinent en aquest article és el conformat per un conjunt d`espais geogràfics culturalment modelats, però no només els immediats a la percepció (paisatge) sino també els de major amplitud...en termes de límits i fronteres (Barabas, 2003)

En parlar de territori abarco, doncs, tres dimensions; d una banda representa un procés producte del conjunt de relacions sòciohistòriques establertes a dins d’un grup i amb els altres grups. En segon lloc tenim el territori com a punt central en la qüestió dels drets indígenes i en relació a llurs demandes (o no) d’autonomia. Aquest punt I’abordaré al següent apartat d’etnodesenvolupament. En darrer lloc tenim el tema del coneixement local sobre les concepcions espacials i les relacions amb I'entorn, incloses les relacions amb les entitats no humanes que I' habiten. EI territori, en aquest sentit, a diferència de conceptes com "espai" o "naturalesa" és habitat i apropiat sota uns determinats límits o marques socials intergrupals.

L' espai territorial dels maies està conformat per una visió intersubjectiva que comprèn el poble, el cementiri, la milpa ${ }^{2}$ i el bosc, amb les entitats que I’habiten. Fins aquí trobem la divisió quatripartita característica de les societats mesoamericanes.A aquest conjunt d`elements $s^{`}$ hi unieixen un altre tipus de

\footnotetext{
2 Sistema agrícola on es plantava fins fa dues dècades diverses varietats de blat de moro combinat amb altres cultius que incouen varietats de llegums, carbassa i alguns tubèrculs.
} 


\section{perifèria}

Número 10, Junio 2009

\section{www.periferia.name}

marcadors com el Santo Patron, la creu, les coves, el decret agrari, I’ ejido. Jo hi afegiria també l'ús quotidià com un altre espai d’interacció a dins del territori.

Els espais territorials son dinàmics i estan submergits constantment a processos de canvi on les marques sígniques van variant amb el temps. Alguns d’aquests marcadors es reforcen, com el culte al Santo Patrón o les creus i d’altres han canviat, com la proliferació d`esglésies diverses. Territoris identificats a partir de diagnòstics, de marques sígniques amb sentit i pràctiques de mobilitat associades i que son respectats tant per la població indígena com mestissa.

\section{Tres estudis de cas}

\section{Yaxley}

Quina és la relació entre la situació socioeconómica de les unitats domèstiques i Ilurs estratègies econòmiques, en relació al territori? Uli Hostettler (1997) en un estudi realitzat el 1989 va trobar que tot a la comunitat de Yaxley, municipi de Noh Kah Santa Cruz Balam (Felipe Carrillo Puerto), Quintana Roo, els processos econòmics locals estan lligats als contextos de l'economia global. Aquesta comunitat enclavada a dins del que anomenem com a Zona Maya ha estat conformada històricament pels processos de mobilitat regionals que afecten a tot l’estat de Quintana Roo. Una bona part de la població d`aqueta zona es considera heretera dels maies rebels de la Guerra de Castas $^{3}$ i s` identifiquen amb el grup dels que van fugir de l’ interior de Yucatán per establir-se a Tixkakal Guardia.

D`acord amb Hoesttetler (1997) malgrat que els maies de Yaxley operen conjuntament els dos sistemes de sabers (I`occidental i el propi) el control estatal sobre els canals de compra/venda regionals dels maies ha causat problemes en la venda d'excedents i els ingressos cada any son menors a la comunitat. Les estratègies flexibles de diversificació i I`adopció de noves activitats econòmiques es

3 Conflicte bèlic entre propietaris tradicionalistes i conservadors que fabricaven la fibra de sisal, centrats sobre tot a la ciutat de Mérida, i la facció de modernistes liberals que s'havien enriquit cultivant la canya de sucre a les terres més humides de l’est. 


\section{perifèria}

Número 10, Junio 2009

\section{www. periferia.name}

porten a terme però son processos llargs i plens de dificultats. L' autora troba que no hi ha un accés homogeni als coneixements no tradicionals fet que provoca processos de diferenciació socioeconòmica.

L' accés a la terra a Yaxley és de caràcter comunal ja que en la cosmovisió maia es contempla a la terra en forma d'usdefruit i no com a propietat particular. Pensem que el 1992 els ejidatarios de Felipe Carrillo Puerto varen votar en contra de la parcel.lació i a favor de la tinença comunal de la terra enfront dels embats del neoliberalisme econòmic de l` estat mexicà qui va privatitzar la possessió de la terra amb la Ley Agraria de 1992 i la modificació a I’Artículo 27 Constitucional. En el context del registre de pràctiques eficients a escala llarga, la conservació és una condició sine quanon per a la supervivència de les comunitats de camperols tradicionalment dependents dels ingressos dels recursos forestals (Doane, 2007)

Les implicacions per a la biodiversitat en aquesta comunitat cal trobar-les, doncs, en les fórmules d’explotació dels recursos del medi forestal. A 1989 la principal font d'ingressos de Yaxley era la milpa, la cria de bestiar, la caça comercial i l'explotació forestal del chicle i el comerç de troncs. Això es combinava amb la producció de verdures, comerç a petita escala i el transport. Els maies de Yaxley combinen el calendari laboral de l’agricultura milpera amb altres formes de treball. Aquí veiem com els maies han portat a terme una manera d’entendre la modernitat, és a dir, incorporant fluxes de coneixement alienes a llurs pròpies experiències basades en el saber local.

El treball assalariat fora de l'ejido porta a la mà d’obra masculina a treballar en la construcció d’hotels a Cancún o Zama (Tulum). Segons Hoesttetler (1997) a Yaxley l'elevada superfície permet el creixement d’una abundant vegetació, molt apta per a l'agricultura milpera. En el centre de Quintana Roo hi ha una certa resistència a pràctiques econòmiques $i$ influències culturals alienes a llur àmbit agrícola tradicional. A més, fins ara, el centre de I'Estat de Quintana Roo s`ha vist com una zona marginal amb poc potencial pel desenvolupament econòmic, degut a 


\section{perifèria}

Número 10, Junio 2009

www. periferia. name

Ilurs limitats recursos naturals i humans

\section{Chan Kom}

En un altre interessant estudi de cas l'antropòloga mexicana Alicia Re (1994) es centra en I'experiència territorial dels emigrants maies de la comunitat rural de Chan Kom a Yucatán cap a Cancún a l’estat de Quintana Roo. Ella parteix de I'existència de dos tipus de representacions espacials: la de l’àmbit rural i la de I'àmbit urbà. Aquests dos pols serveixen de circuit migratori tot i que no representen la dicotomia funcionalista entre tradició i modernitat. Pel contrari, segons l'autora, les experiències dels emigrants a Cancún es veuen reforçades per representacions maies tradicionals, com els yuntziles, els aluxes o la concepció cosmològica basada en la divisió quatripartita de l’ univers.

Cancun és un ambient sociocultural on l'indígena es fon i s`intercanvia amb el turisme de masses. Els conceptes d'"exòtic" i "món màgic" defineixen política i culturalment la realitat de Cancún a través d'hotels en forma de piràmide o l'ús de la força de treball maia com a aborigen. En aquest context la cultura és objectivada (Santana, 2003) i despersonalitzada, treta de context amb la finalitat d’obtindré un producte presentable com autèntic, fora de temps, que ha d’infondre la idea de I'experiència inoblidable. No obstant, a les àrees populars, on el turisme no entra és on viuen els maies contemporanis, un món de marginació i pobresa cròniques.

El moviment migratori va suscitar a Chan Kom un cert sentiment d "autenticitat" del que és pròpiament maia, és a dir, que els maies de Cancún ja no eren "autèntics maies" ja que un maia no deixa mai de fer la milpa. És a dir que el símbol de la milpa no només es converteix en una marca identitària sinó que també és un mecanisme per desidentificar als emigrants que van del poble a Cancún. En canvi pels maies de Cancún ells segueixen "haciendo milpa" produïnt riquesa, com si aquesta ciutat fos una esplèndida i fructífera milpa on no s`hi planta blat de moro però si hi ha acumulació de capital i negocis diversos. Aquí veiem una dicotomització entre uns 'nosaltres' (camperols) i un 'ells' (emigrants) on el blat de moro i la milpa passen a través del constructe territorial de Cancún a simbolitzar 


\section{perifèria}

Número 10, Junio 2009

www.periferia. name

elements de valor no menys autèntics. La incorporació de la milpa en el seu territori citadí, la seva identitat, la forma de vida urbana ens porta a pensar en el paper que ocupen els rituals catòlics en el seu univers identitari i aquests ens permeten llegir el seu concepte de territori.

\section{X-Kopchen}

Em va cridar l'atenció que aquesta informació lligava amb la que ens parla Valentina Vapnarlky (2000) sobre els modus d’interacció verbal que s`accionen en els diàlegs cerimonials de transmissió de responsabilitats entre els maies contemporanis de la comunitat de X-Kopchen, al centre de Quintana Roo. Els seus estudis posen en evidència l'existència de formes monologades i dialogades en els diàlegs rituals catòlics que es correspon a una forma particular de solidaritat $\mathrm{i}$ comunalitat. Allà observa que les processions maies contemporànies segueixen un curs circular que comença per l’est- sud- nord-oest. Aquests diàlegs per I’autora revelen un tipus de reciprocitat entre les accions dels diversos interlocutors.

Les peregrinacions i processons que realitzen els pobles amerindis mesoamericans poden llegir-se, segons Barabas (et. al., 2004) com a trajectes realitzats sobre espais i territoris simbolitzats cap a un santuari o centre sagrat. Les processions referenden les fronteres interiors mentre que les peregrinacions actuen com a marcadors de territoris ètnics de caràcter històric. Aquesta estreta relació entre santuaris, processons i peregrinacions reforça la idea que els maies tenen sobre el territori que autoalimenta formes d’ una cultura expressiva (Cook, 2000)

Els maies de X-Kopchen porten el Santo Patrono catòlic a coll des d’aquesta població de Quintana Roo fins els pobles de I`orient de I`estat de Yucatán. Durant el trajecte visiten unes 12 viles al llarg de trenta quilòmetres. Per a protegir el sant hi ha una compañía o grup organitzat d homes que porten a terme la mobilitat d'aquest juntament amb pràctiques dialògiques amb els encarregats dels pobles que els reben. Aquests diàlegs revelen I' ús de locucions de caràcter espacial que es manifesten a través de sut uhèel (estratègies de reciprocitat), comunicació amb el 


\section{perifèria}

Número 10, Junio 2009

www.periferia. name

sagrat i nup'tanba (complementarietat) (Vapnarslky, 2000). .

Els maies de Quintana Roo creen i signifiquen nous espais construïts social i culturalment i simbolitzats religiosa o civilment. Les processions i visites al Santo Patrón son marcadors del territori i contenen la unió entre els camps de la política i la religió com a elements de jerarquia i reciprocitat. Les festes, processons, els càrrecs, l’església i la imatge del sant (o imatge) porten tota la parafernàlia associada, els discursos, formen mun complexe ritual i mític al voltant del culte al Santo Patrón titular del poble, que, segons Nolasco (2003), sosté i té efecte sobre la consolidació i continuïtat o sobre la tranformació o recreació d` un ordre normatiu i altres estructures simbòliques i de interrelació social.

\section{Etnodesenvolupament}

Etnodesenvolupament és la disciplina que defineix el conjunt de sabers en funció dels quals cada grup humà anomena i classifica el seu entorn (Levesque, 1996) Aquests coneixements no es queden, només, en l'àmbit de l'entorn sino que s'inserten en altres contextes com els econòmics o els simbòlics (Siebers, 2004) Això implica no la transposició de nocions occidentals a les altres cultures (etnociència) sinó que aquestes darreres tenen quelcom realment important a dir quant a l’autogestió dels recursos de cada regió.

Es pot parlar d'un etnodesenvolupament entre els maies de Quintana Roo? La Ley de Derechos, Cultura y Organización Indígenas del Estado de Quintana (1998) fa un èmfasi especial en la relació entre els pobles maies i l’entorn del que formen part. No obstant i això ja veurem que no s’esmenten alternatives d’organització autònoma pròpies. Això vol dir que el discurs administratiu-polític dels governs federal y estatals continua dominant i imposant els seus criteris. Segons Demarest (2004), per alguns autors, això vol dir que el pensament occidental tendeix a veure els sistemes polítics I econòmics maies com a versions incompletes, o "menys evolucionades" que el propi. La ideologia i la cosmovisió son vistes com una fascinant col.lecció $d$ 'idees esotèriques que fascinen als investigadorstend $\mathrm{i}$ al 


\section{perifèria}

Número 10, Junio 2009

\section{www.periferia.name}

públic encuriosit en general.

L'etnodesenvolupament contempla que hi ha una certa autonomia dels sistemes de referències indígenes en relació a llurs pràctiques. Això és degut a que els sistemas històrics han transformat aquest coneixement al llarg del temps. Coneixements que no es queden en l'àmbit de l'entorn sino que s' inserten en altres contextos com els econòmics o els simbòlics. L`explotació de I’ecosistema marí a Quintana Roo, per exemple, avui igual que ahir, es continua fent ja que aquest proveeix recursos múltiples en espècies gastronòmiques $d$ 'un alt valor nutricional, peix, moluscs $i$ carn. Els maies de Zama (Tulum) combinen els usos de materials del mar amb articles de consum adquirits al mercat canviant l'antic pagament en grans de cacau per adoptar l’economia del peso o el dolar.

Algunes organitzacions socials de Quintana Roo com Amigos de Sian Ka'an han adoptat el discurs mediambiental per portar a terme accions encaminades a protegir l'entorn de l'increment accelerat de l'activitat humana. La Reserva de la Biosfera de Sian Ka'an amb una extensió de mig milió d’hectàrees conté els tres ecosistemes principals de la regió, selva mitjana i baixa, aiguamolls, manglars, sabana, dunes costeres. Aquesta zona està molt despoblada i s'enfronta a l’amenaça de l'ocupació humana a través del turisme, la pesca comercial i esportiva, però també l'amenacen els incendis forestals, els huracans i els problemas legals per la tinença de la terra. L`ejido ${ }^{4}$ Pino Suárez de Zama (Tulum) periòdicament ocupa territori de la reserva per a construïr vivendes o negocis turístics."

Quintana Roo té una superficie forestal que comprèn 3, 200,000 hectàrees d’un total de 5, 048,300 hectàrees del territori en total. D`aquests espais els governs locals han destinat 487,829 hectàrees a l'ús forestal permanent i com a explotació per a diverses societats productores com la Sociedad de Productores Forestales

\footnotetext{
${ }^{4}$ Un ejido és el nom amb el que es coneixen històricament una forma comunal de tinença de la terra que té els seus orígens en l'assignació estatal d espais forestals i agropecuaris a les comunitats indígenes de Mèxic per a llur explotació durant I`etapa postrevolucionaria.
} 


\section{perifèria}

Número 10, Junio 2009

www. periferia. name

Ejidales de Quintana Roo, la Organización de Ejidos Productores Forestales de la Zona Maya S.C (OEPF), la Sociedad de Pueblos Indígenas Forestales de Quintana Roo "Tumben Cuxtal" S.C., la Organización de Ejidos Productores Forestales de Quintana Roo "Chaktemal" S.C., i els Ejidos forestales de la zona norte del Estado. A més d`aquests espais cal agregar les reserves pròpies dels ejidos que, si bé son molt més petites que les esmentades tenen una gran importancia tant per a 「 extensió com per el que signifiquen a nivell comunal.

Els maies de Quintana Roo, marginats dels beneficis que comporta I'hiperdesenvolupament de platges i centres urbans, han combinat I'agricultura intensiva amb l’explotació forestal. La ramaderia és una activitat incipient que encara està en plè procés de creixement i els cultius comercials com la canya de sucre solen estar associats a la població mestissa. En canvi l’horticultura és una activitat compartida per tota la població i compta amb subvencions gubernamentals. També a la zona es practica la caça, la recol.lecció i la utilització de materials de I'entorn per a construïr vivendes, tot i que cada vegada menys degut a l’esgotament dels recursos.

El sistema agrícola característic dels maies de la regió és la milpa, el terreny de cultiu que conté un coneixement específic sobre I’entorn ecològic, I`ús de plantes i el cicle pluvial. També és característic el sistema de descans del bosc o guaret per a mantenir els nivells aceptables de productivitat. Hi ha esforços per part de les institucions governamentals per sedentaritzar la milpa combinada amb incentius per tal de mantenir la coberta forestal. Aquestes temptatives xoquen en moltes ocasions amb les polítiques implementades per altres dependències estatals que atorguen incentius per ampliar àrees de pastura o cultius comercials amb més problemes de corrupció i subutilització dels recursos atorgats (Ruz et. al, 1999). Aquest aspecte afegeix una sobrecàrrega als ecosistemes i propicia la desaparició del bagatge cultural. Penso en el saber dels maies com un factor fonamental per entendre la biodiversitat però que això és compatible, també, amb la producció agrícola i forestal comercial. 


\section{perifèria}

Número 10, Junio 2009

www. periferia. name

\section{Drets indígenes dels maies de Quintana Roo}

A l’article 2 del Títol Primer de la Ley de Derechos, Cultura y Organización Indígena del Estado de Quintana Roo, aprobada pel Congrés local al 1998, que he esmentat abans, s`afirma que els pobles "originaris" han d’ésser reconeguts i preservats en els seus drets i cultura i l’ estat es compromet a tenir una nova relació amb aquests grups tendents a promoure el seu benestar. En l'article 4 es reconeix l'existència d`una comunitat indígena maia que té centres cerimonials, dignataris, festes tradicionals i una institució que organitza tot això anomenada Gran Consejo Maya. Alhora és important de notar que es coneix l’existència d`altres grups ètnics a la regió la cultura i el benestar dels quals ha d`ésser igualment protegit per la llei.

La llei proclama, també, que el patrimoni cultural és indissoluble al medi ambient i als recursos naturals propis del territori dels maies. No obstant en cap moment es delimita territorialment aquesta Zona Maia sinó que queda subjugada a la entitat territorial administrativa de I`estat mexicà anomenada Quintana Roo.

De 2003 a 2005 deu Jueces Tradicionales de la comunitat maia local van divulgar la Ilei a les 41 comunitats dels municipis de Felipe Carrillo Puerto i José María Morelos i a la Zona Maya en general (Moure, 2006). Segons Recio (2006) una de les crítiques que ha rebut la Llei és que el Gran Consejo Maya és una institució trasplantada d’altres regions de Mèxic que estableix la figura d’un magistrat indígena i de jutges tradicionals, aquests càrrecs son completament aliens a la estructura tradicional dels maies macehuales de Quintana Roo. A més de formes alienes d`organització els lligams d’alguns dirigents maies amb organitzacions governamentals com I' Instituto Nacional Indigenista o el Instituto Quintanaroense de Cultura fa que existeixi un fort divisionisme al sí de les organitzacions pan-maies de la regió.

Un tema en el que es posa èmfasi és el capítol IX que està dedicat íntegrament al dret a I'autonomia del pobles maies de Quintana Roo incloent el dret a la lliure determinació però només en referència a la normativa interna de convivència. També s`esmenta que qualsevol expressió d`autonomia ha de tenir com a marc 


\title{
perifèria
}

\author{
Número 10, Junio 2009
}

\section{www. periferia. name}

I'Estat mexicà. Aquí veiem com, novament, les lleis aprovades pels Congressos del poder regional mexicà es sobreposa a una possible demanda territorial com a part implícita d`aquesta autonomia.

Segons dades de premsa de la regió alguns governs locals han proposat al govern federal la seva incorporació a la gestió del Parque Nacional de Tulum i al Parque Arqueológico Tulum-Tanká. En un pla de gestió a nivell micro seria possible incorporar elements dels sabers propis dels maies de la regió els quals tenen la seva pròpia versió sobre cóm ha d'estar la relació entre el ser humà, el territori i les entitats que I' habiten. Això xoca amb els interessos de grans institucions a nivell nacional com I'Instituto Nacional de Antropología e Historia (INAH) i la Secretaría de Medio Ambiente, Recursos Naturales y Pesca (SEMARNAP) que tenen una visió tendent a preservar el nacionalisme mexicà i amb les grans cadenes hoteleres instal-lades a la regió les quals tenen també els seus propis interessos econòmics.

\section{Conclusions}

L`aportació d’aquest article és que la dualitat naturalesa/cultura pot ésser desarticulada mitjançant la deconstrucció del concepte de territori. Més si tenim en compte que ni territori ni territorialitat són conceptes que estiguin inclusos en el mapa conceptual dels maies, però que son incorporats al corpus de sabers com uns nous instruments que utilitzar al seu favor. Des d'un punt de vista etic, els sistemes de sabers dels maies de Quintana Roo, llurs nocions territorials, al.ludeixen sovint a formes de treball de la terra, sistemes de govern, estragègies de movilitat i signes de sacralitat particulars. Des d’un punt de vista emic, aquestes nocions no poden ésser enteses sense un treball de camp que permeti aprofundir en la interpretació dels possibles significats inherents al repertori cultural dels maies. Aquesta via potencia encara més la perspectiva crítica antidualista que desautoritza la universalitat de conceptes com naturalesa o cultura.

Les pràctiques sòcioespacials dels maies de Quintana Roo proposen la construcció d’un territori que es fonamenta en I’experiencia de una movilitat prèvia d’una població acostumada històricament als desplaçaments. L`arribada dels europeus a 


\section{perifèria}

Número 10, Junio 2009

\section{www.periferia.name}

les costes de Yucatán va desarticular les formes d’organització territorial de la població local i va modificar llur relació amb l’entorn. Però aquesta mateixa població va posar en pràctica un conjunt d`estratègies de mobilitat que inclouen la negociació i incorporació d’elements territorials aliens, en ocasions, i en d’altres la clandestinitat de pràctiques espacials adaptades a l’ecosistema del bosc plujós tropical.Ells persisteixen en el seu dinamisme que els porta a migrar no sols a Cancún sino també als Estats Units, construint nous espais d`interacció i noves formes d`entendre l`entorn i de transformar-lo.

Els tres estudis de cas esmentats en aquest article posen sobre la taula uns conceptes de territori i entorn que remet a unes dualitats (camp-ciutat, local-global, material-sagrat) que els maies posen en qüestió a través de les interaccions que realitzen amb diferents agents (maies i mestissos) Ja veiem com la Ley de Derechos, Cultura y Organización Indígena del Estado de Quintana Roo (1998) ha aixecat veus crítiques, veus d`agents locals que desessencialitzen el concepte d' etnicitat que postula I’actual govern mexicà. D`altra banda seria interessant aprofundir en I`estudi de les relacions entre població maia i mestiza a Quintana Roo que podria posar en evidència les incorporacions $i$ desincorporacions d’elements culturals propis i aliens.

Els maies de Quintana Roo activen el conjunt de sabers propis del que Ärhem (1996) anomena com una ecosofia tot relligant aspectes de I'entorn amb reivindicacions de carácter ètnic? No sembla pas fins ara que així sigui de una forma explícita però el que sí és cert és que les organitzacions pan-maies de Quintana Roo com el Movimiento Nación Maya o Meyajut'ial ma'aloob k'inoob (Associació de comunitats i organitzacions indígenes), organitzacions com Amigos de Sian Ka'an, i publicacions com El correo de la selva s'han apropiat del discurs ecologista d occident per incorporar-lo al corpus de reivindicacions territorials. Això posa en evidència el aspectes dinàmics de la cultura maia, la seva permeabilitat a I'accés de pautes noves: continuen utilitzant les mateixes estratègies exitotes que els ha permès persistir al llarg dels segles. 


\section{perifèria}

Número 10, Junio 2009

\section{www.periferia.name}

Els maies de Quintana Roo han posat en pràctica estratègies adaptatives sòlidament anclades a pràctiques de mobilitat sobre diversos territoris. Estratègies que es caracteritzen per la seva creativitat i flexibilitat per incorporar nous elements de la cultura global al seu sistema de sabers i a llurs pràctiques quotidianes. Sabers maies que ara tenen més difusió gràcies a la recentment oberta Universidad Intercultural de la Zona Maya, amb programes de televisió emesos en llengua maia i publicacions periòdiques.

Els maies utilitzen discursos propis de llur cosmovisió per elaborar una modernitat alternativa. Davant de l’empresa colonitzadora occidental que entén els espais com quelcom per ésser omplert, apropiat, usat, una empresa que és biocèntrica i etnocèntrica, els maies oposen una combinació de sabers que han moldejat i elaborat al llarg dels segles i que ha mostrat la seva eficacia. Concepcions autòctones que enenten I’entorn com una configuració holística amb línies ofertes a les connexions biosocials. Territoris que poden ésser explotats per activitats agrícoles o ramaderes però que també poden ésser transitats i viscuts amb altres entitats no humanes que també formen part d`aquests espais i també els necesiten per existir.

\section{Bibliografía}

Albert, Bruce (2004). Territorialidad, etnopolítica y desarrollo. A propósito del movimiento indígena en la Amazonía brasileña, a Alexandre Surrallés y Pedro García Hierro (eds.) Tierra adentro. Territorio indígena y percepción del entorno. IWGIA, Copenhague, pp. 221-258

Barabas, Alicia M. (2003). Introducción: una mirada etnográfica sobre los territorios simbólicos indígenas, a Barabas, Alicia M (coord.) Diálogos con el territorio. Simbolizaciones sobre el espacio en las culturas indígenas de México. Vol I. Instituto Nacional de Antropología e Historia, México, pp.13-16.

Boada, Martí y Víctor Toledo (2003). El planeta, nuestro cuerpo. La ecología, el ambientalismo y la crisis de la modernidad. Fondo de Cultura Económica, México.

Burns, Allan F. (1993). Voz y poesía en la filosofía maya-yucateca de la muerte, a Ma..Josefa Ponce de León y Francesc Ligorred Perramon, Perspectivas antropológicas en el mundo maya. Sociedad Española de Estudios Mayas/Instituto de Cooperación I beroamericana. Madrid, pp. 479-496.

Cook, Garret W. (2000). Religious Sodalities of Momostenango. The Comunnal Cult Institutions, a Renewing the Maya World Expressive Culture in a Highland Town. 


\section{perifèria}

Número 10, Junio 2009

\section{www. periferia. name}

University of Texas Press, Austin.

Demarest, Arthur (2006). Ancient Maya. The Rise and Fall of a Rainforest Civilzation. Cambridge University Press, U.K.

Descola, Philippe (2005). Par- delà natue et culture. Editions Gallimard, Paris.

Di Meo, Guy i Pascal Bulèon (2005). L'espace social. Lecture góographique des sociétés. Aramand Colin, Paris.

Doane, Molly (2007). The Political Economy of the Ecological Native, American Anthropologist vol 109, pp.452- 462.

Fromm, Eric. (1980). Tenir o ésser. Editorial Claret S.A., Barcelona.

Gutiérrez Estévez, Manuel (1995). De la conversación yucateca al diálogo cristiano y viceversa, a Varios (eds.) De palabra y obra en el Nuevo Mundo. 4-Tramas de identidad. Siglo XXI de España editores, Madrid, pp. 171-234

- (2006). Dualismo y mestizaje en la identidad de los mayas de Yucatán, a Montserrat Ventura Oller, Ariadna Lluís i Vidal-Folch i Gabriella Della Corte, La frontera, entre límits i ponts. Casa Amèrica de Catalunya, Barcelona, pp. 159-172.

H.VIII Legislatura Constitucional del Estado Libre y Soberano de Quintana Roo. (1998). Decreto 140: Ley de Derechos y Organización Indígena del Estado de Quintana Roo, en Constitución Política del Estado Libre y Soberano de Quintana Roo, Artículo 13. Periódico Oficial.

Hannerz, Ulf (1992). Cultural Complexity Studies in the Social Organizations of Meaning. Columbia University Press, New York.

Hoestettler, Uli (1997). Estratificación socioeconómica y economía doméstica en el municipio de Felipe Carrillo Puerto, Quintana Roo, a Ramón Arzápalo y Ruth Gubler (comp.) Persistencia Cultural entre los mayas frente al cambio y la modernidad. Ediciones de la Universidad Autónoma de Yucatán. Mérida, Yucatán, México, pp. 1741.

Lasserre, Frédéric et Aline Lechaume (2003). Le territoire pensé. Géographie des répresentations territoriales. Presses de l'Université du Québec, Canada.

Leff, Enrique (2000). La complejidad ambiental. Ed. Siglo XXI, Madrid.

Levesque, Carole (1996). La nature culturelle. Trajectories de I'anthropologie écologique contemporaine, a Anthropologie et Sociétés, vol 20, no 3. Paris, pp. 514.

Lomelí González, Arturo (1999). Pueblos indios y autonomías zapatistas, a Araceli Burguete Cal y Mayor (coord.) México: experiencias de Autonomía Indígena. Documento IWGIA no 28. Grupo Internacional de Trabajo sobre Asuntos Indígenas, Copenhague, Dinamarca, pp. 210-233.

Maceiras Fabián, Manuel (2007). La experiencia como argumento. Clasicismo y posmodernidad. Editorial Síntesis S.A., Madrid.

Moure, Julio. (2006). Apuntes deshilachados sobre la identidad cultural, a El Correo de la selva. Revista bimestral de Tulum y áreas circunvecinas. Producciones Selva 


\section{perifèria}

Número 10, Junio 2009

www.periferia.name

Libre, Tulum, pp.16-17.

Paz y Miño, Guillermo (1998). El valor de la diversidad biológica y sus vínculos con la diversidad cultural, a F.Díaz Pineda, J.M de Miguel y M.A.Casado (coord.) Diversidad biológica y cultura rural en la gestión ambiental del desarrollo. Universidad Complutense de Madrid/Ediciones Mundi-Prensa/Multi/Media Ambiental, S.L., Madrid, pp.57-64.

Possey, Darrell (2002). Upsetting the sacred balance. Can the study of indigenous knowledge reflect cosmic connectedness?, a Paul Sillitoe, Alan Bicker\& ohan Pottier, Participating in Development. Approaches to Indegenous Knowledge. Routledge, London\&New York, pp. 24-42.

Re Cruz, Alicia. (1994). Lo sagrado y lo profano en la identidad maya de los emigrantes de Yucatán, a Nueva Antropología 14:16. México, pp. 39-48.

Recio, Justo. (2006). ¿Es anacrónica la ley de justicia y la ley de derechos, cultura y organización indígena del Estado de Quintana Roo?, a El Correo de la Selva. Revista bimestral de Tulum y áreas circunvecinas. Producciones Selva Libre, Tulum, pp. 21-22.

Ruz, Mario Humberto (coord.). (1999). Corredor biológico Mesoamericano. Prospección social en tres microregiones entorno de Sian Ka'an. Banco Mundial/Centro de Estudios Mayas/IIFI/UNAM, México.

Siebers, Hans (2004). Management of knowledge and social transformations: A case study from Guatemala, Alan Bicker, Paul Sillitoe and Johan Pottier, Development and Local Knowledge. Routledge, London and New York, pp. 31-50.

Sillitoe, Paul (2002). Participant observation to participatory development. Making anthropology work, at Paul Sillitoe, Alan Bicker\& Johan Pottier, Participating in Development. Approaches to Indigenous Knowledge. Routledge, London and New York, pp. 1-23.

Vapnarsky, Valentina (2000). De dialogues en prières, la procesión des mots, à Aurora Monod Becquelin et Philippe Ericsson (eds.) Les rituels du dialogue. Promenades Ethnolinguistiques en terres amérindiennes. Recherches Thématiques 6. Société d' Ethnologie, Paris, pp. 431-480. 